\title{
Penyediaan Fasilitas Hunian di Perumahan KORPRI Salatiga: Realita dan Konsep Neighborhood Unit
}

\author{
Housing Facilities Provision in KORPRI Salatiga Housing: Reality \\ and Neighborhood Unit Concept
}

\section{S Sunarti ${ }^{1}$, Nany Yuliastuti ${ }^{1}$, Wido Prananing Tyas ${ }^{1}$, Dwi Putri Puspa Sari ${ }^{1}$}

Diterima: 5 Maret 2020

Disetujui: 1 April 2020

\begin{abstract}
Perumahan KORPRI di Kota Salatiga adalah salah satu bentuk penyediaan rumah murah untuk mengatasi masalah backlog bagi pegawai negeri sipil yang belum memiliki rumah. Sejak dibangun pada tahun 2014, hingga saat ini belum $100 \%$ pembangunan terealisasi, terutama dalam penyediaan fasilitas hunian. Studi ini bertujuan untuk mengkaji lingkungan fisik hunian berdasarkan penyediaan fasilitas di perumahan KORPRI, Praja Mulia, dalam perspektif neighbourhood unit sebagai konsep penataan fisik lingkungan hunian ideal. Metoda yang digunakan yakni kuantitatif dengan menggunakan teknik analisis deskriptif. Teknik pengumpulan data primer dilakukan dengan cara observasi dan interpretasi citra, data sekunder berasal dari dokumen dan studi literatur terkait pembangunan perumahan KORPRI. Hasil penelitian menunjukkan bahwa berdasarkan konsep neighborhood unit, sebagai perumahan murah, Perumahan Praja Mulia dengan jumlah penduduk rencana sebanyak 1.380 jiwa memiliki fasilitas unit lingkungan yang tidak ideal. Fasilitas yang ada hanya ruang terbuka berupa taman lingkungan dan lapangan olahraga yang terletak di 3 lokasi ( $3 \%$ dari total luas perumahan) dan fasilitas umum lainnya masih dalam rencana. Novelti penelitian ini bahwa perumahan untuk PNS tidak menggunakan teori neighborhood unit tetapi hanya memperhatikan rumah sebagai benda (noun) yang digunakan untuk investasi dan komoditas.
\end{abstract}

Keyword: fasilitas perumahan, neigborhood unit, KORPRI, aksesibilitas

\begin{abstract}
KORPRI housing in Salatiga City is one form of providing low-cost housing to overcome the backlog problem for civil servants who do not yet have a home. Since it was built in 2014, until now not $100 \%$ development has been realized, especially in the provision of residential facilities. This study aims to examine the physical environment of housing based on the provision of facilities in KORPRI housing, Praja Mulia, in the perspective of a neighborhood unit as a physical structuring concept of an ideal residential environment. The method used is quantitative by using descriptive analysis techniques. Primary data collection techniques are carried out by means of observation and interpretation of images, secondary data derived from documents and literature studies related to KORPRI housing development. The results showed that based on the concept of neighborhood units, as cheap housing, Praja Mulia Housing with a planned population of 1,380 inhabitants had non-ideal neighborhood unit facilities. The existing facilities are only open spaces in 3 locations (3\% of the total housing area) and other public facilities that are still planned. Novelti of this research housing for civil servants do not use environmental unit theory but only pay attention to the house as objects (nouns) used for investment and commodity.
\end{abstract}

Keywords: housing facilities, neighborhood unit, KORPRI, accessibility

\footnotetext{
${ }^{1}$ Departemen Perencanaan Wilayah dan Kota, Fakultas Teknik, Universitas Diponegoro
} 


\section{PENDAHULUAN}

Neighborhood tidak memiliki definisi yang disepakati, secara umum neighborhood diartikan sebagai skala teritorial terkecil dari kehidupan suatu kota (Jensen, 2020). Menurut Hasanuddin (2014), neighborhood merupakan lingkungan fisik dengan fasilitas sosial, budaya, pendidikan, komersial yang mudah dijangkau dan juga merupakan tempat untuk memenuhi kebutuhan sehari-hari. Berdasarkan definisi tersebut, perumahan merupakan salah satu bentuk dari sebuah neighborhood. Perumahan terdiri atas kumpulan rumahrumah yang dilengkapi dengan prasarana, sarana, dan utilitas umum (Peraturan Menteri Permahan Rakyat Republik Indonesia No. 07 tahun 2013) sebagai tempat bermukim manusia dalam melangsungkan kehidupannya. Elemen struktural sebuah neighborhood yaitu jalan masuk, jaringan akses, dan pusat lingkungan, serta ruang tempat tinggal (Habib, Moztarzadeh, \& Hodjati, 2013).

Lingkungan hunian merupakan tempat penting bagi penghuni untuk berpartisipasi ke dalam masyarakat perkotaan yang lebih luas melalui pertukaran informasi, interaksi sosial, serta akses ke layanan dan fasilitas (Zou, Chen, \& Chen, 2019). Penyediaan fasilitas lingkungan yang harus dipenuhi untuk melayani area tertentu guna menciptakan hunian yang ideal antara lain: pendidikan, kesehatan, perbelanjaan, peribadatan, sarana olahraga dan ruang terbuka (Hasanuddin, 2014). Hal ini berarti, dalam sebuah unit lingkungan, keberadaan fasilitas penting untuk memenuhi kebutuhan harian penduduk dalam batasan spasial. Penelitian lain menyatakan pemanfaatan fasilitas sosial di perumahan berdasarkan variabel ketersediaan, lokasi dan aksesibilitas, intensitas pemanfaatan, dan interaksi sosial antar penghuni, menunjukkan bahwa sarana yang memiliki efektivitas tertinggi ke terendah antara lain: peribadatan, perdagangan, taman dan lapangan olahraga, pendidikan, balai RW dan pos ronda, dan kesehatan (Sukmawati \& Yuliastuti, 2014). Aksesibilitas fasilitas sosial berperan penting mempengaruhi penggunaan fasilitas tersebut (Yuliastuti, Sukmawati, \& Purwoningsih, 2018).

Studi lain menunjukkan menunjukkan bahwa pembangunan perumahan dikaitkan dengan akses terhadap fasilitas yang diperlukan untuk menciptakan lokasi hunian yang fungsional, nyaman, estetis, dan aman (Igwe, Okeke, Onwurah, Nwafor, \& Umeh, 2017). Lebih lanjut, selain mengatasi masalah backlog, pembangunan perumahan bertujuan untuk memenuhi kebutuhan layanan dan infrastruktur masyarakat (Ibem, 2012). Di sisi lain, pembangunan perumahan baru tidak selalu diimbangi dengan penyediaan infrastruktur yang sesuai (Kellett \& Nunnington, 2019). Temuan sebuah studi di Nigeria menyatakan bahwa dalam pembangunan perumahan baru untuk masyarakat berpenghasilan rendah lebih fokus pada pembangunan unit rumah dibandingkan dengan aksesibilitas terhadap layanan dasar dan fasilitas bagi penghuni (Ibem, 2012). Fasilitas sosial di perumahan formal yang dikembangkan oleh sektor privat lebih efektif dibandingkan dengan sektor publik (Yuliastuti dkk., 2018).

Penelitian terdahulu tentang rumah murah fokus pada upaya agar MBR dapat mengakses dan menjangkau rumah layak huni (Average, 2019; Baqutaya, Ariffin, \& Raji, 2016); indikator-indikator berkelanjutan (Karji dkk, 2019); hingga identifikasi faktor keberhasilan kerja sama dalam pembangunan perumahan murah di Indonesia (Rachmawati dkk, 2018). Belum banyak yang mengkaji keberhasilan pembangunan perumahan murah dalam menciptakan lingkungan hunian yang ideal.

Neighbourhood unit merupakan konsep desain fisik ideal dari lingkungan hunian dalam memenuhi kebutuhan sosiopsikologi penghuninya (Putri, Subulussalam, Rahayu, \& Ramadhan, 2016) dan memberikan peluang interaksi sosial antar penghuni (Asfour \& Zourob, 2017). Konsep neighborhood unit memberikan pedoman perencanaan ruang dan fasilitas yang dapat mendukung aktivitas rutin masyarakat dalam batas spasial (Byun, Choi, \& Choi, 2014). Sejak pertama kali dipopulerkan, neighborhood unit terus berkembang menyesuaikan dengan perkembangan zaman (Hasanuddin, 2019). 
Konsep neighbourhood unit telah diimplementasikan di berbagai negara baik maju maupun berkembang dengan konteks sosial, ekonomi, dan perkotaan yang berbeda (Asfour \& Zourob, 2017). Prinsip-prinsip neighborhood unit dapat diadopsi sebagai fokus penataan fisik lingkungan perumahan di Indonesia dengan ciri masyarakat yang terbiasa bersosialisasi (Hasanuddin, 2019). Menurut Perry sebagai pencetus konsep, neighbourhood unit mencakup area seluas $16.000 \mathrm{~m}^{2}$ yang memungkinkan anak-anak untuk berjalan tidak lebih dari 804,672 m (0,5 mil) ke sekolah dengan 10\% luasnya dialokasikan untuk tempat rekreasi (Eisner, Gallion, \& Eisner, 1993; 269). Lingkungan hanya digunakan sebagai akses layanan bagi penghuni dalam sebuah neighborhood unit. Layanan-layanan minimal yang disediakan dalam neighborhood unit antara lain: fasilitas perdagangan di bagian pinggir, sarana ibadah, perpustakaan, dan community center yang lokasinya berdekatan dengan sekolah.

Perumahan Praja Mulia di Kota Salatiga adalah salah satu wujud pembangunan perumahan baru secara formal sebagai penyediaan rumah murah bagi masyarakat berpenghasilan rendah, khususnya untuk pegawai negeri sipil anggota KORPRI. Pembangunan perumahan ini didukung oleh program pembiayaan berupa KPR bersubsidi yang melibatkan kolaborasi berbagai stakeholder dalam prosesnya (Sunarti, Yuliastuti, \& Indriastjario, 2018a). Harga unit rumah di Perumahan Praja Mulia adalah Rp.83,5 juta, di bawah harga standar perumahan bersubsidi yang ditetapkan oleh pemerintah sebesar Rp.130 juta. Dengan harga yang sedemikian rendah, pertanyaan yang muncul adalah apakah penghuni mendapatkan kelengkapan fasilitas hunian yang ideal?

Berbagai permasalahan yang muncul yaitu pembangunan rumah, fasilitas dan prasarana belum terealisasi $100 \%$ dan sebagian penghuni bukan PNS sebagai pemilik rumah, namun disewakan dan bahkan dijual ke orang lain. Berdasarkan fenomena di lapangan dan studi tetang neighbourhood yang belum dilakukan oleh peneliti sebelumnya di perumahan untuk PNS, maka peneliti tertarik dalam penelitian ini mempunyai tujuan untuk mengkaji penyediaan fasilitas di Perumahan Prajamulya dalam perspektif neighbourhood unit sebagai konsep penataan fisik lingkungan hunian ideal. Artikel ini menyajikan fakta kondisi lapangan dan kajian rencana fisik lingkungan perumahan berdasarkan konsep neighborhood unit. Dengan demikian, studi ini diharapkan dapat menjadi bahan pertimbangan bagi pemerintah daerah dalam memenuhi kebutuhan pelayanan fasilitas umum dan sosial di perumahan.

\section{METODE PENELITIAN}

Metode yang digunakan dalam penelitian ini yaitu kuantitatif dengan teknik analisis deskriptif dengan pendekatan spasial. Teknik pengumpulan data primer yang digunakan yaitu observasi lapangan, interpretasi citra, dan kuesioner. Observasi lapangan untuk melakukan verifikasi fasilitas perumahan berdasarkan jumlah, jenis, sebaran, dan kondisi eksisting fasilitas yang ada di Perumahan Praja Mulia apakah sesuai dengan rencana atau tidak. Intepretasi peta dilakukan berdasarkan citra yang diambil dari Google Earth. Selain itu, kuesioner digunakan untuk mengidentifikasi karakteristik penduduk dan mengidentifikasi kebutuhan fasilitas berdasarkan jawaban responden sebanyak 20 orang yang mewakili rumah tangga.

Teknik analisis yang digunakan adalah intepretasi peta yang dibandingkan dengan site plan Perumahan Prajamulia dan hasil observasi dilakukan untuk mengidentifikasi jenis dan jumlah guna memetakan sebaran fasilitas yang direncanakan. Analisis yang dilakukan pada tahap selanjutnya, hasil digitasi berfungsi sebagai alat untuk menghitung luasan kavling yang diperuntukkan bagi pembangunan fasilitas. Kemudian, dilakukan analisis penyediaan fasilitas hunian yang terdiri atas pendidikan, kebudayaan, sosial, peribadatan, dan komersial di internal Perumahan Praja Mulia berdasarkan kondisi empiris dan perspektif konsep neighborhood unit. 


\section{Konsep Neighborhood Unit dan Penerapannya di Indonesia}

Neighborhood unit terus berkembang menyesuaikan dengan perkembangan zaman dan secara fleksibel dapat diterapkan dengan menyesuaikan konteks lokal (Hasanuddin, 2019). Sebuah studi tentang adaptasi dan penerapan konsep neighborhood unit di Asia berdasarkan 4 metode konfigurasi yakni (1) ukuran lingkungan; (2) struktur lingkungan; (3) jaringan lingkungan, dan (4) fasilitas lingkungan menyimpulkan bahwa ukuran lingkungan paling mempengaruhi yang lain (Lee \& Park, 2018). Ukuran lingkungan mengacu pada elemen lingkungan fisik dan populasi. Kaitannya dengan analisis fasilitas ideal dalam penelitian ini, area fisik dan populasi menjadi elemen penting yang diperhatikan. Adapun dii Indonesia, pedoman teknis yang umumnya digunakan dalam perencanaan perumahan dan permukiman adalah SNI dengan prinsip-prinsip utama yang diadaptasi sesuai dengan konsep neighborhood unit (Lestari, Faqih, \& Santosa, 2014).

Enam prinsip konsep neighborhood unit antara lain: (1) ukuran, (2) batas wilayah, (3) jalan internal, (4) ruang terbuka, (5) area institusi, dan (6) pertokoan lingkungan (Habib dkk., 2013). Ukuran berarti pengembangan sebuah unit perumahan harus menyediakan tempat tinggal dan sekolah yang bergantung pada populasi. Batas merujuk pada batas fisik perumahan yang berupa jalan-jalan untuk memfasilitasi lalu lintas di sekitarnya. Jalan internal merupakan jalan khusus yang dirancang untuk memfasilitasi sirkulasi di dalam unit dan terbebas dari hiruk pikuk lalu lintas. Ruang terbuka berupa taman kecil dan ruang rekreasi harus disediakan dan direncanakan untuk memenuhi kebutuhan lingkungan tertentu. Area institusi berarti area sekolah dan institusi lain dengan fungsi layanan sesuai dengan batas unit lingkungan harus dikelompokkan secara tepat sebagai pusat lingkungan. Pertokoan lingkungan berjumlah satu atau lebih yang memadai untuk melayani populasi penghuni, berada di sekeliling unit dan ideal berada di persimpangan jalan. Komponen neighborhood unit adalah entrance atau pintu masuk, jaringan akses lokal, neighborhood center atau pusat lingkungan, dan residential spaces atau ruang hunian (Habib dkk., 2013).

\section{PEMBAHASAN}

\section{Perumahan Praja Mulia sebagai Sebuah Neighborhood}

Perumahan Praja Mulia berlokasi di Kelurahan Randuacir, Kecamatan Argomulyo, yang merupakan kawasan pengembangan permukiman di Kota Salatiga. Perumahan tersebut dibangun dengan menggunakan lahan aset pemerintah eks tanah bengkok seluas $\pm 48.115 \mathrm{~m}^{2}$. Jumlah Penduduk Kelurahan Randuacir sebanyak 6.395 jiwa (3.205 laki-laki dan 3.190 perempuan) yang terbagi atas 2.069 kepala keluarga pada tahun 2018 (Badan Pusat Statistik, 2018), sedangkan jumlah kepala keluarga di perumahan Praja Mulia sebanyak 171 KK (8,3\%) dari total jumlah penduduk di Kelurahan Randuacir). Sebagai gambaran lokasi perumahan Prajamulia orientasi terhadap Kota Salatiga dapat dilihat pada Gambar 1 dibawah ini.

Berdasarkan rencana tapak (site plan) Perumahan Praja Mulia, dari $48.115 \mathrm{~m}^{2}$ total luas lahan, $28.328 \mathrm{~m}^{2}$ (59\%) dialokasikan untuk kavling rumah dan $19.787 \mathrm{~m}^{2}$ (41\%) untuk sarana dan prasarana perumahan. Fasilitas atau sarana yang direncanakan untuk melayani penghuni antara lain: taman yang tersebar di 6 titik lokasi, 1 masjid, 1 gereja, 2 lapangan olah raga, 1 minimarket, dan 1 balai RW, namun sampai sekarang semua fasilitas yang direncanakan belum semua terbangun. Dari pengembang tidak ada tanggung jawab untuk membangun fasilitas tersebut dan dari pemerintah belum ada rencana program untuk melengkapi fasilitas yang direncanakan tersebut. Status lahan untuk fasilitas yang belum terbangun kepemilikannya masih menjadi milik pemerintah daerah. Penggunaan lahan dengan persebaran fasilitas pada setiap blok dapat dilihat pada Gambar 2. 


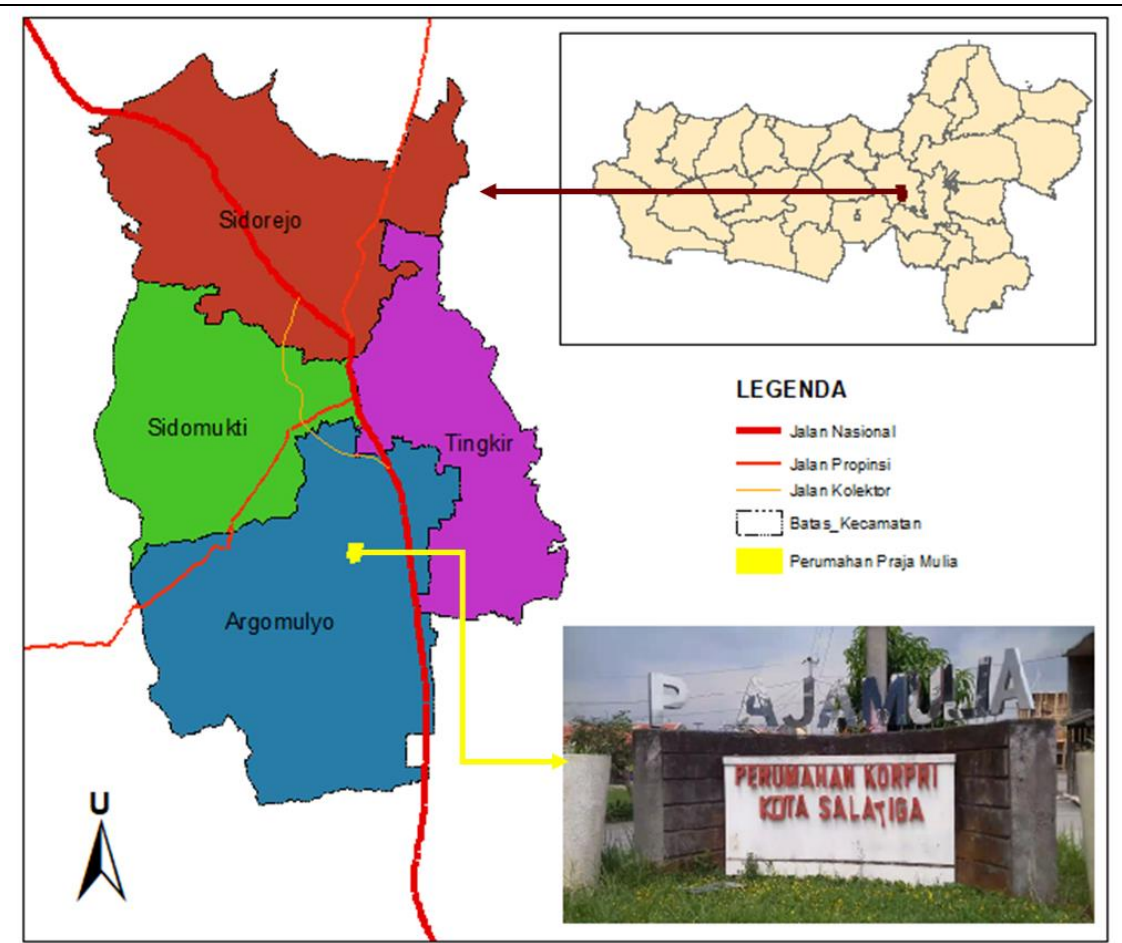

Sumber: Hasil Analisis Peneliti, 2019

Gambar 1. Peta Orientasi Perumahan Prajamulia, Kelurahan Randuacir, Kecamatan Argomulyo, Kota Salatiga

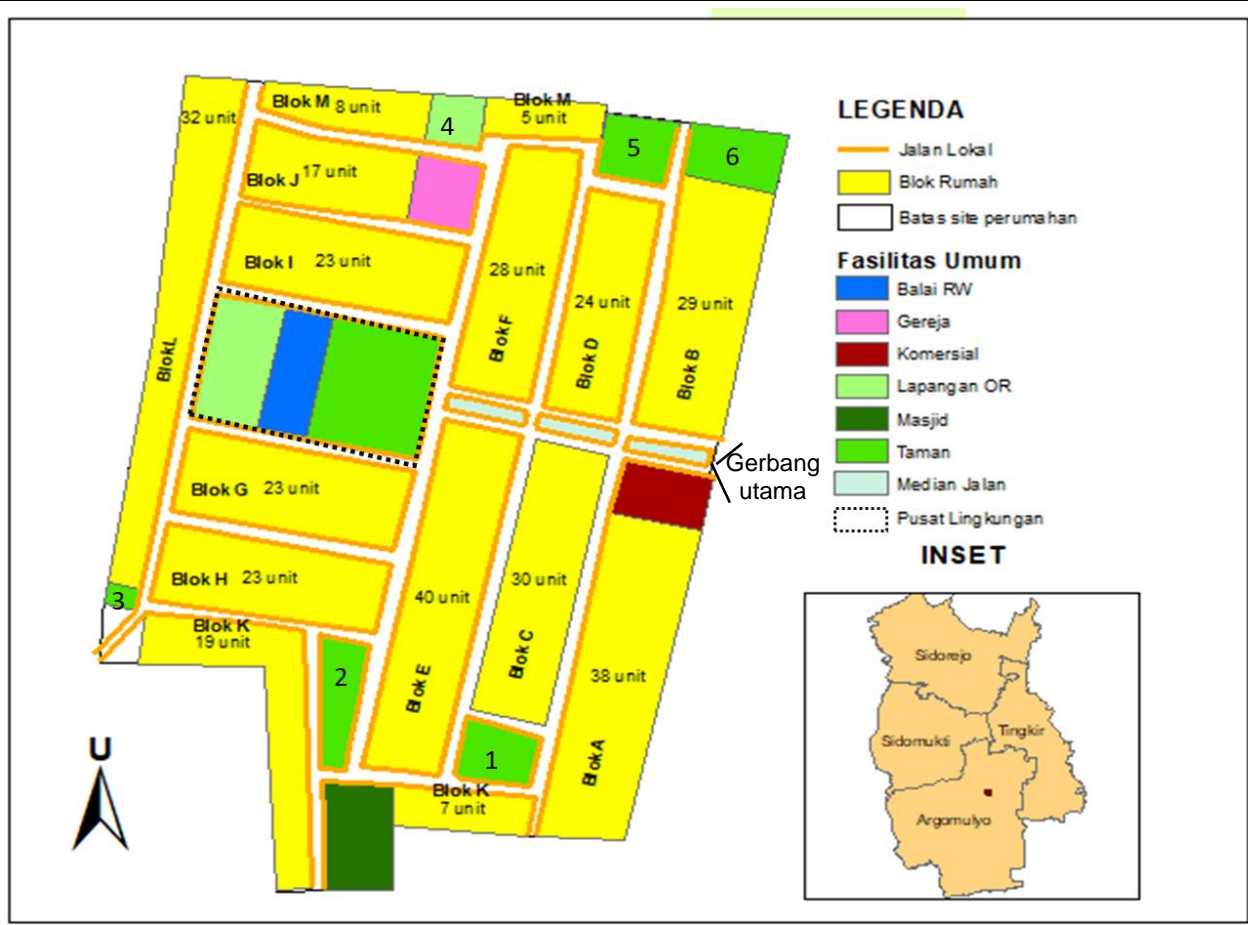

Sumber: Hasil Analisis Peneliti Berdasarkan Citra Google Earth, 2019

Gambar 2. Site Plan Perumahan Praja Mulia 
Perumahan Praja Mulia adalah salah satu wujud neighborhood, apabila dilihat dari komponen neighborhood (Habib dkk., 2013) yaitu pintu masuk, jaringan akses lokal, pusat lingkungan, dan ruang hunian. Komponen pintu masuk berupa gerbang utama perumahan bertuliskan "Perumahan Praja Mulia" yang dapat dengan jelas diidentifikasi oleh masyarakat umum sebagai pintu masuk. Komponen jaringan akses lokal berupa jaringan jalan lokal yang berada di dalam perumahan dengan perkerasan paving yang digunakan oleh penghuni untuk melakukan pergerakan yang minim aktivitas lalu lintas sehingga aman. Pusat lingkungan perumahan berupa kumpulan kavling fasilitas yang terdiri atas balai warga, lapangan olahraga, dan taman di tengah-tengah perumahan. Ruang hunian terdiri atas bangunan rumah tipe $36 / 72 \mathrm{~m}^{2}$ sejumlah 345 unit yang terbagi atas 12 Blok yaitu A hingga L.

\section{Kondisi Empiris Fasilitas Hunian Eksisting di Perumahan Praja Mulia}

Site plan perumahan Praja Mulia merupakan hasil pemikiran dari pengembang yang disetujui oleh Kepala Bidang Tata Ruang dan Bangunan Kota Salatiga serta diketahui oleh Kepala Dinas Cipta Karya dan Tata Ruang Kota Salatiga. Berbeda dengan pembangunan perumahan privat yang seluruh konstruksinya dibebankan pada pengembang, pembangunan Praja Mulia melibatkan kolaborasi berbagasi stakeholder di dalamnya (Sunarti, Yuliastuti, \& Indriastjario, 2018b). Konstruksi sarana dan prasarana dalam perumahan dibantu oleh pemerintah dan dinas terkait dengan biaya yang berasal dari APBD Kota Salatiga. Walaupun memiliki faktor pendorong berupa kebijakan pembiayaan pembangunan fasilitas yang jelas (Rachmawati dkk, 2018) yakni bersumber dari APBD Kota Salatiga, banyak fasilitas yang ada dalam rencana hingga kini belum terbangun. Berkaitan dengan hal ini, berdasarkan penelitian yang sama (Rachmawati dkk, 2018), faktor kurangnya komitmen pemangku kepentingan menyebabkan tidak berhasilnya kerja sama dalam realisasi secara menyeluruh Pembangunan Perumahan Praja Mulia.

Total rumah yang dibangun di Perumahan Praja Mulia sebanyak 345 unit dengan tipe 36/72 m2. Masing-masing unit rumah didesain memiliki 2 kamar, 1 ruang tamu, 1 kamar mandi, dan 1 dapur. Berdasarkan SNI 03-1733-2004 tentang Tata Cara Perencanaan Lingkungan Perumahan di Perkotaan, kebutuhan ruang minimal per orang yaitu 9,6 m2. Hal ini menunjukkan bahwa rumah tipe $36 / 72 \mathrm{~m} 2$ yang ada idealnya dihuni oleh keluarga kecil dengan jumlah anggota keluarga paling banyak 4 jiwa. Berdasarkan standar tersebut, diketahui bahwa Perumahan Praja Mulia secara ideal dihuni oleh total penduduk sebanyak 1.380 jiwa. Dengan demikian, kebutuhan fasilitas ideal untuk memenuhi kebutuhan penghuni baik berdasarkan jumlah penduduk maupun unit lingkungan (RW) dijabarkan dalam Tabel 1.

Tabel 1. Penyediaan Fasilitas Perumahan Ideal untuk Penduduk 1.380 Jiwa Berdasarkan Standar Nasional Indonesia

\begin{tabular}{|c|c|c|c|c|c|}
\hline $\begin{array}{l}\text { Kategori } \\
\text { Fasilitas }\end{array}$ & Jenis Sarana & $\begin{array}{c}\text { Jumlah } \\
\text { Penduduk } \\
\text { Pendukung } \\
\text { (SNI) }\end{array}$ & $\begin{array}{c}\text { Kebutuhan } \\
\text { Fasilitas (SNI) }\end{array}$ & $\begin{array}{c}\text { Jumlah } \\
\text { Fasilitas yang } \\
\text { Terbangun }\end{array}$ & Keterangan \\
\hline \multirow[t]{2}{*}{ Pendidikan } & TK & 1.250 & 1 & 0 & $\begin{array}{l}\text { Tidak ada } \\
\text { dalam rencana }\end{array}$ \\
\hline & SD & 1.600 & 1 & 0 & $\begin{array}{l}\text { Tidak ada } \\
\text { dalam rencana }\end{array}$ \\
\hline Kebudayaan & Balai Warga & 2.500 & 1 & 0 & $\begin{array}{l}\text { Masih dalam } \\
\text { rencana }\end{array}$ \\
\hline Sosial & $\begin{array}{l}\text { Taman atau } \\
\text { lapangan } \\
\text { olahraga di } \\
\text { tengah }\end{array}$ & 250 & 6 & 2 & $\begin{array}{l}\text { Masih dalam } \\
\text { rencana }\end{array}$ \\
\hline
\end{tabular}




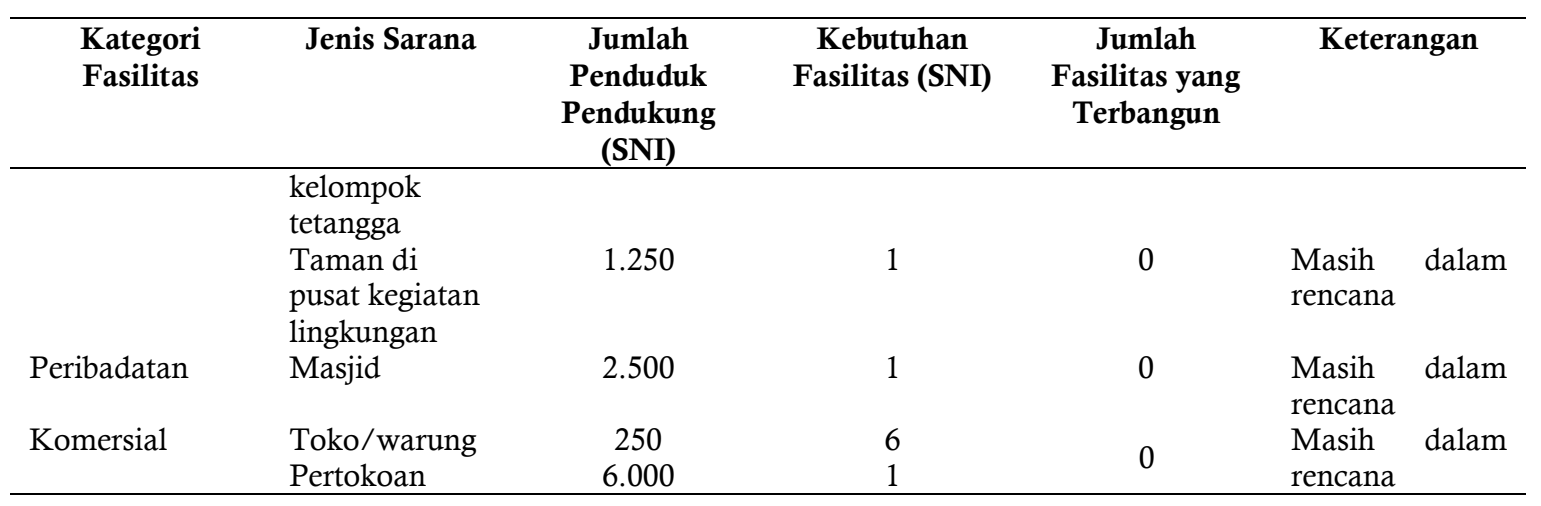

Sumber: Hasil Analisis Peneliti, 2019

Tabel 1 menunjukkan bahwa berdasarkan kondisi empiris, penyediaan fasilitas di Perumahan Praja Mulia belum sesuai dengan kebutuhannya. Bahkan fasilitas pendidikan tidak ada dalam rencana (Gambar 2). Berdasarkan hasil kuesioner, komposisi usia responden yang paling banyak yaitu dalam rentang usia 31 s.d. 40 tahun $(45 \%)$, kemudian $15 \%$ untuk usia di bawah 30 tahun, $20 \%$ untuk rentang usia 41 s.d. 50 tahun, dan masingmasing $10 \%$ untuk rentang usia 51 s.d. 60 tahun dan kelompok umur $>60$ tahun.

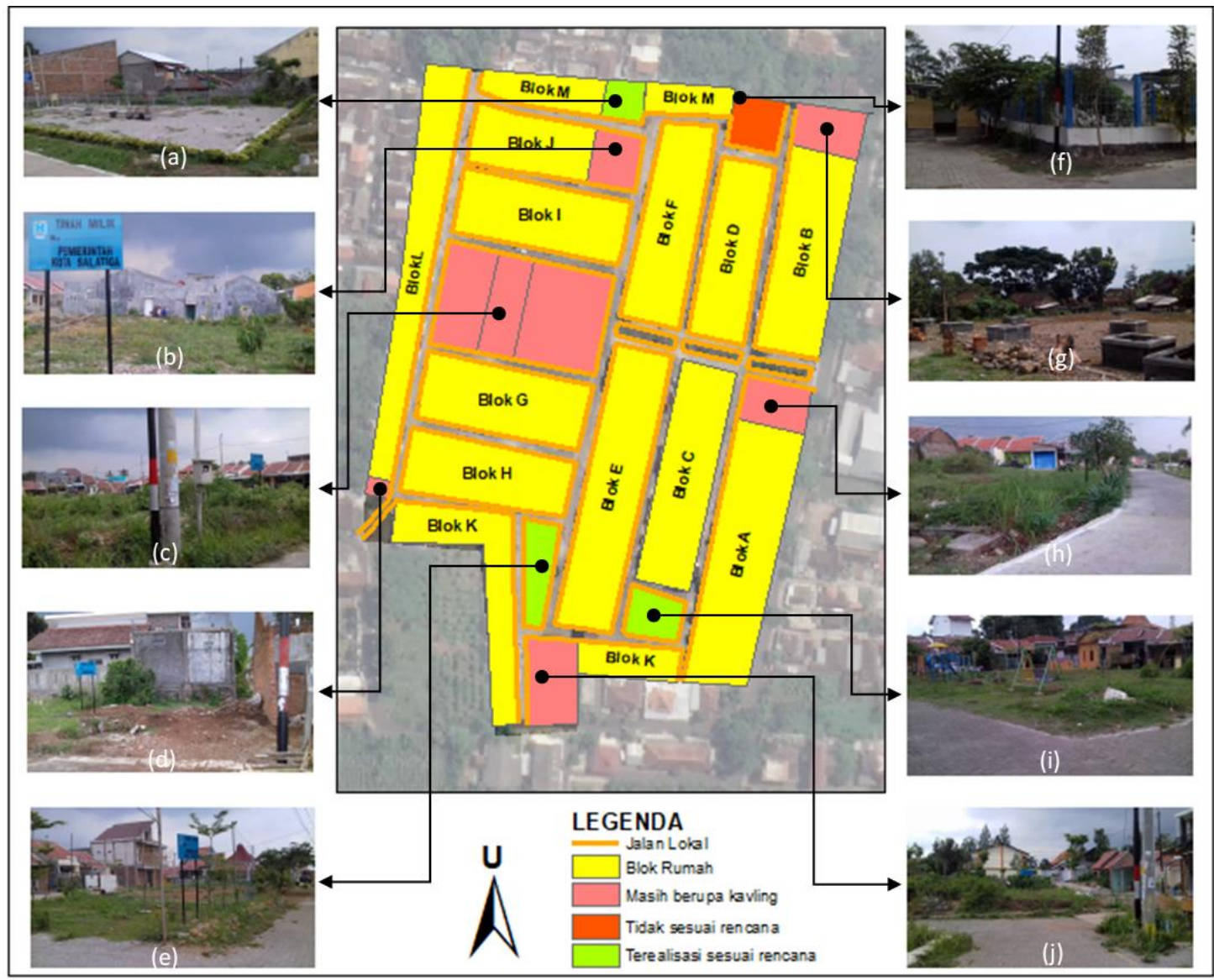

Sumber: Analisis Peneliti, 2019

Gambar 3. Kondisi Eksisting Fasilitas Umum dan Sosial di Perumahan Prajamulia 
Dominasi responden dengan rentang umur 31-40 tahun menunjukkan bahwa Perumahan Praja Mulia dihuni oleh keluarga muda yang minimal membutuhkan fasilitas sekolah berupa PAUD dan TK di lokasi perumahan tersebut. Selain itu, beberapa fasilitas yang sudah terbangun tidak sesuai dengan fungsi peruntukkan kavling yang direncanakan. Lebih jelasnya dapat dilihat pada Gambar 3.

Gambar 3 merupakan hasil analisis berdasarkan verifikasi kondisi lapangan. Apabila Gambar 2 dan Gambar 3 dibandingkan, terlihat bahwa beberapa kavling belum dibangun sesuai dengan peruntukan dan beberapa yang telah terbangun tidak sesuai dengan peruntukkan awalnya (tidak sesuai rencana). Fasilitas yang realisasinya sesuai dengan rencana adalah ruang terbuka. Walaupun demikian, realita tersebut hanya ada pada 3 dari 6 lokasi ruang terbuka yakni 2 lokasi taman di bagian Selatan dan 1 lapangan olahraga di Utara.

Di sisi lain, banyak fasilitas yang hingga kini belum terbangun bahkan cenderung terbengkalai. Dibuktikan dengan kavling-kavling peruntukkan fasilitas yang ditumbuhi oleh rumput liar. Kavling yang realisasinya tidak sesuai (Gambar 3(f)), pada awalnya direncanakan untuk membangun taman, realitanya berupa bangunan instalasi air. Kemudian untuk Gambar 3(g), tampak pernah dilakukan pembangunan namun tidak selesai. Pusat lingkungan yang terdiri dari fasilitas 1 balai warga, 1 lapangan olahraga, dan 1 taman (Gambar 3(c)) belum tersedia atau masih berupa rencana. Kondisi yang sama juga terdapat pada kavling untuk fasilitas komersial (Gambar 3(h)), peribadatan berupa masjid (Gambar 3(j)) dan gereja (Gambar 3(b), serta 1 taman di tengah kelompok tetangga Blok H-K-L (Gambar 3(e)).

Realita ini menunjukkan bahwa fasilitas yang ada belum mampu melayani kebutuhan minimal penghuni secara ideal. Kondisi ini memperkuat temuan penelitian oleh Ibem (2012) bahwa dalam pembangunan perumahan baru untuk masyarakat berpenghasilan rendah (murah) tidak fokus pada aksesibilitas fasilitas bagi penghuni melainkan fokus pada pembangunan unit rumahnya saja. Hal ini diperkuat oleh fakta di lapangan bahwa saat ini, jumlah rumah yang dihuni adalah 182 unit (53\%) dengan status 92 milik sendiri, sedangkan 90 yang lain berstatus sewa. Artinya 163 unit (47\%) dibiarkan kosong dan $26 \%$ disewakan yang mengindikasikan bahwa bangunan tersebut bukan merupakan rumah pertama pemilik. Bahkan, sebagian bangunan yang ada sudah bukan milik pemilik pertama atau dengan kata lain telah diperjualbelikan/dipindahtangankan. Dengan demikian dapat ditarik kesimpulan bahwa sebagian PNS penerima bantuan rumah murah tidak memanfaatkan rumah yang didapat sesuai dengan tujuan dan sasaran pembangunan rumah murah melainkan hanya untuk investasi dan tidak memperdulikan kebutuhan tentang fasilitas di perumahan tersebut sehingga banyak pembangunan fasilitas yang belum terlaksana hingga sekarang. Padahal, hunian tidak hanya sebagai bangunan fisik (noun) yang dapat diperjualbelikan, lebih dari itu, rumah merupakan tempat untuk proses dalam suatu kehidupan (Turner, 1976).

\section{Analisis Kelengkapan Fasilitas Berdasarkan Perspektif Konsep Neighbourhood Unit}

Luas area Perumahan Praja Mulia yakni $48.115 \mathrm{~m}^{2}$ terdiri atas 345 unit rumah. Selain luas, ukuran lingkungan mengacu pada elemen populasi (Lee \& Park, 2018) yang disesuaikan dengan konteks lokal. Ukuran lingkungan dari Perumahan Praja Mulia dengan populasi rencana sebanyak 1.380 jiwa adalah rukun warga, dengan jumlah penduduk pendukung berdasarkan standar yaitu 2.500. Secara administrasi, Perumahan Praja Mulia merupakan satu kesatuan unit lingkungan RW 09, Kelurahan Randuacir, Kecamatan Argomulyo, Kota Salatiga.

Berdasarkan hasil kuesioner, jumlah anggota keluarga tiap unit yaitu 4,25 jiwa. Jadi, penghuni unit lingkungan Perumahan Praja Mulia eksisting adalah 774 jiwa (56\% penduduk rencana). Kemudian, walaupun perumahan diperuntukkan bagi PNS, namun 
saat ini banyak penghuni yang bukan PNS. Hanya 25\% yang anggota keluarganya menjadi PNS. Sesuai dengan pernyataan (Lee \& Park, 2018) bahwa ukuran lingkungan paling mempengaruhi konfigurasi berdasarkan fasilitas hunian. Terlihat dari Tabel 1, bahwa jumlah seluruh fasilitas secara ideal ditentukan berdasarkan jumlah penduduk yang dilayani.

Berdasarkan site plan yang dapat dilihat pada Gambar 2, fasilitas yang ada di Perumahan Praja Mulia tidak memenuhi penyediaan layanan minimal berdasarkan konsep neighborhood unit (Eisner, Gallion, \& Eisner, 1993; 269). Hal ini dilihat berdasarkan analisis menurut prinsip-prinsip neighborhood unit yaitu ruang terbuka, area institusi, dan pertokoan lingkungan (Habib dkk., 2013).

Ruang terbuka berupa taman kecil dan ruang rekreasi harus disediakan dan direncanakan untuk memenuhi kebutuhan lingkungan tertentu. Berdasarkan Tabel I terlihat bahwa kebutuhan ruang terbuka berjumlah 6. Berdasarkan rencana (Gambar 2), penyediaan fasilitas ruang terbuka sudah sesuai dengan kebutuhan. Rencana ruang terbuka terdiri atas: taman dan lapangan olahraga seluas $5.525 \mathrm{~m}^{2}$ atau $11,5 \%$ dari luas total. Berdasarkan luasan rencana, ruang rekreasi yang ada sesuai bahkan melebihi konsep neighborhood unit yakni 10\% dari total luasnya (Eisner, Gallion, \& Eisner, 1993; 269). Akan tetapi, seperti yang telah dibahas pada bahasan sebelumnya, bahwa hanya tiga lokasi yang terealisasi yakni seluas $1.139 \mathrm{~m}^{2}$. Artinya ruang rekreasi yang saat ini telah tersedia di Perumahan Praja Mulia hanya 2,37\% dari luas total, sehingga berdasarkan kondisi eksisting lapangan tidak sesuai dengan konsep neighborhood unit.

Area institusi berarti area sekolah dan institusi lain dengan fungsi layanan sesuai dengan batas unit lingkungan harus dikelompokkan secara tepat sebagai pusat lingkungan (Habib dkk., 2013). Di Perumahan Praja Mulia, area institusi direncanakan tidak sempurna hanya terdiri dari balai RW, lapangan olahraga dan taman tanpa adanya sekolah. Padahal, dalam konsep neighborhood unit, sekolah merupakan fokus orientasi dalam penyediaan layanan unit lingkungan, sementara sekolah justru sama sekali tidak tersedia baik rencana maupun realisasinya.

Pertokoan lingkungan telah direncanakan berupa minimarket yang berada di persimpangan jalan dekat dengan gerbang utama perumahan. Lokasi ini berdasarkan konsep neighborhood unit tergolong ideal, namun sayang faktanya tidak ada.

Tidak lengkapnya fasilitas yang ada di Perumahan Praja Mulia sejalan dengan pernyataan dalam penelitian dari Yuliastuti dkk (2018), bahwa penyediaan fasilitas di perumahan formal yang dikembangkan oleh sektor privat lebih efektif dibandingkan dengan sektor publik. Perumahan yang dibangun tanpa adanya akses terhadap fasilitas membuat lokasi hunian tidak fungsional (Igwe dkk., 2017) sehingga dapat membebani unit lingkungan di sekitarnya untuk memperoleh layanan fasilitas yang tidak terdapat pada lingkungan tempat tinggalnya.

Apabila dikaitkan dengan penghuni yang saat ini ada di Perumahan Praja Mulia, dengan total penghuni perumahan sebanyak 774 jiwa dan ketersediaan ruang terbuka berupa 2 taman dan 1 lapangan olah raga, tidak menjadi masalah bagi lingkungan sekitar, karena dengan standar penduduk pendukung 250 jiwa, 3 ruang terbuka tersebut sudah cukup memenuhi kebutuhan 774 penduduk. Akan tetapi untuk kebutuhan lainnya seperti fasilitas pendidikan TK (Taman Kanak-kanak) yang dibutuhkan, Kelurahan Randuacir pada tahun 2018, hanya memiliki 4 unit sekolah. Jumlah tersebut tidak mampu melayani kebutuhan TK bagi penduduk kelurahan sendiri sebanyak 6.395 jiwa, karena paling tidak Kelurahan Randuacir harus memiliki fasilitas pendidikan TK sebanyak 5 unit. Bahkan, jika dilihat fasilitas pendidikan TK pada lingkungan kelurahan sekitarnya (Tabel 2) di Kecamatan Argomulyo, fasilitas yang ada sebagian besar tidak mampu memenuhi kebutuhan di masing-masing kelurahan itu sendiri, sehingga tidak adanya fasilitas TK di perumahan baru seperti Praja Mulia dapat menambah beban dari unit lingkungan lain dalam menyediakan fasilitas pendidikan apalagi dengan status penghuni yang hampir $50 \%$ - 
nya merupakan penyewa yang setiap kurun waktu tertentu dapat berbeda-beda (dinamis). Adapun perencanaan berdasarkan RP3KP Kota Salatiga 2036 pun tidak ada perhitungan kebutuhan untuk fasilitas pendidikan TK melainkan SD, SLTP dan SLTA yang persebarannya dapat dilihat pada gambar 4 .

Tabel 2. Penyediaan Fasilitas Pendidikan TK di Kecamatan Argomulyo

\begin{tabular}{|c|c|c|c|c|}
\hline Kecamatan & $\begin{array}{c}\text { Jumlah Penduduk } \\
\text { Tahun } 2019 \\
\text { (Disdukcapil) }\end{array}$ & $\begin{array}{c}\text { Jumlah Eksisting } \\
\text { TK }\end{array}$ & $\begin{array}{c}\text { Kebutuhan TK } \\
\text { menurut SNI } \\
\text { (Jumlah Penduduk } \\
\text { Pendukung } 1.250 \\
\text { jiwa) }\end{array}$ & Analisa \\
\hline Noborejo & 6.618 jiwa & 3 & 6 & Kurang \\
\hline Cebongan & 5.065 jiwa & 4 & 4 & Memenuhi \\
\hline Randuacir & 6.395 jiwa & 4 & 6 & Kurang \\
\hline Ledok & 11.101 jiwa & 2 & 9 & Kurang \\
\hline Tegalrejo & 12.423 jiwa & 5 & 10 & Kurang \\
\hline Kumpulrejo & 8.179 jiwa & 2 & 7 & Kurang \\
\hline
\end{tabular}

Sumber: Hasil Analisis Peneliti, 2019

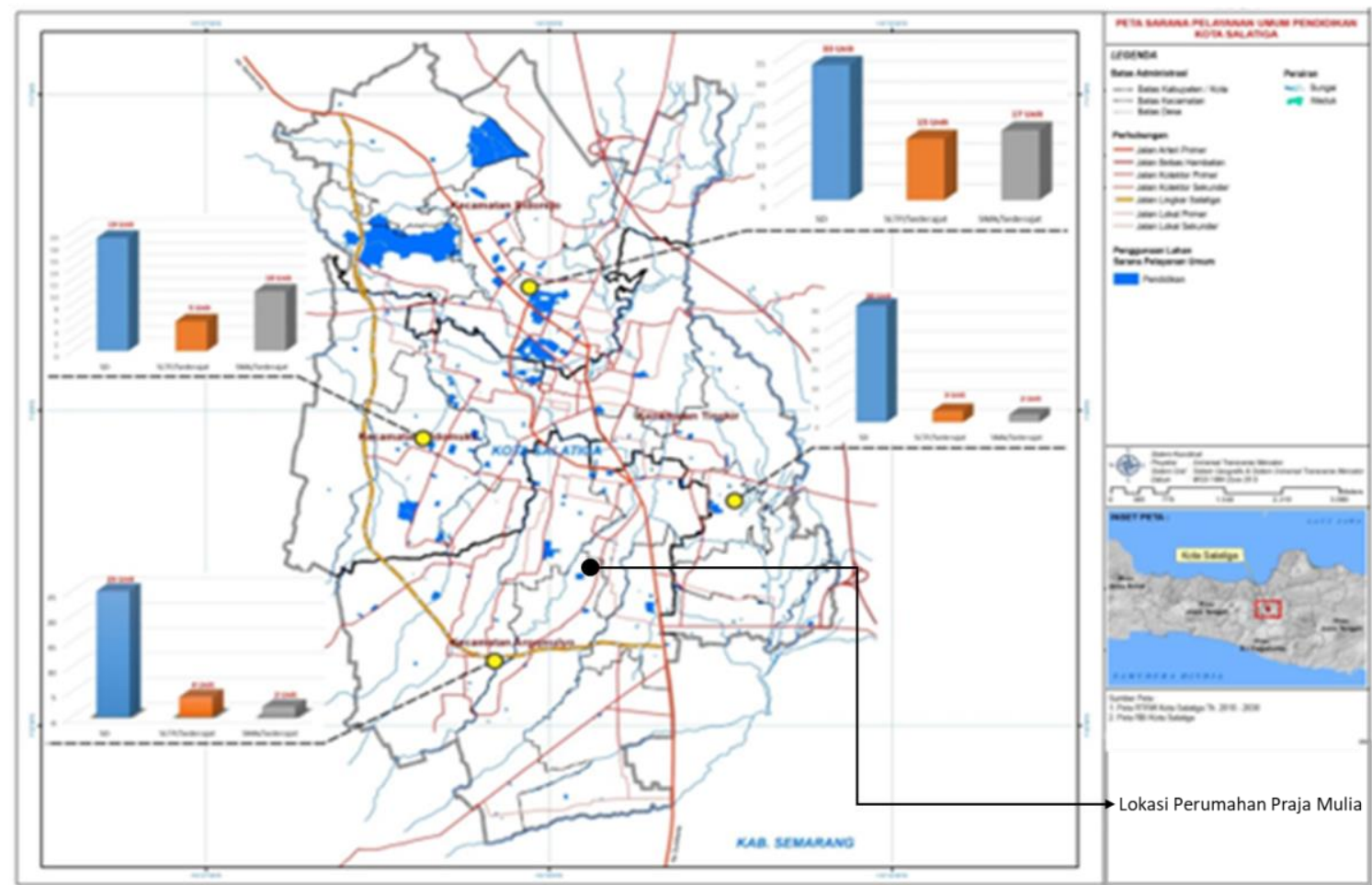

Sumber: Badan perencanaan, Penelitian, dan Pengembangan Daerah Kota Salatiga, 2017

Gambar 4. Peta Rencana Pelayanan Umum Pendidikan Kota Salatiga

Hasil analisis berdasarkan konsep neighborhood unit, menunjukkan bahwa penyediaan fasilitas di Perumahan Praja Mulia kurang ideal. Perencanaan fasilitas hunian kurang memperhatikan jumlah populasi (ukuran lingkungan). Fasilitas sekolah sebagai salah satu elemen pusat lingkungan tidak direncanakan. Akses fasilitas yang tidak tersedia di lingkungan hunian tertentu menyebabkan seseorang akan mencari akses fasilitas di luar 
lingkungannya. Hal tersebut terjadi secara rutin karena fasilitas yang harusnya disediakan dalam unit lingkungan perumahan berkaitan dengan aktivitas rutin masyarakat dalam batas spasial (Byun, Choi, \& Choi, 2014).

\section{KESIMPULAN}

Perumahan Praja Mulia merupakan unit lingkungan RW dengan populasi 1.380 jiwa. Perhitungan kebutuhan fasilitas disesuaikan berdasarkan konteks lokal yakni menggunakan SNI yang secara prinsip sesuai dengan konsep neighborhood unit (Lestari dkk., 2014). Berdasarkan analisis yang dilakukan, disimpulkan bahwa penyediaan fasilitas hunian di Perumahan Praja Mulia baik secara realita maupun konsep neighborhood unit tidak ideal. Realita menunjukkan bahwa hanya fasilitas ruang terbuka berupa 3 dari 6 taman yang tersedia atau terealisasi. Sementara fasilitas lainnya yakni pendidikan, peribadatan, kebudayaan, dan komersial tidak ada atau masih berupa rencana. Menurut konsep neighborhood unit, elemen dasar sama sekali tidak direncanakan yaitu sekolah, sehingga area institusi yang terdiri atas sekolah dan institusi lainnya sebagai pusat lingkungan (Habib dkk., 2013) tidak tersedia. Adapun jenis sekolah sesuai ukuran lingkungan yang seharusnya ada yaitu TK dan SD. Tidak ada. Sementara, fasilitas lain sesuai prinsip yakni ruang terbuka dan pertokoan yang direncanakan sudah sesuai bahkan untuk ruang terbuka luasan yang diperuntukkan lebih yakni $11,5 \%$ dari paling tidak $10 \%$ luas total.

Kondisi ini menunjukkan bahwa penyediaan fasilitas di dalam Perumahan Praja Mulia secara ideal belum mampu melayani populasi yang direncanakan. Hal tersebut memberikan beban dan menjadi tantangan bagi kota dan lingkungan di sekitarnya dalam menyediakan fasilitas dan layanan bagi penduduk yang tidak terlayani pada unit lingkungan tempat tinggalnya. Penyediaan fasilitas sebuah kota perlu lebih memperhatikan jumlah penduduk yang belum terlayani oleh fasilitas internal huniannya guna memenuhi kebutuhan sehari-hari. Studi lanjutan terkait fenomena yang terjadi di masyarakat dalam sebuah unit lingkungan yang mendapat beban untuk melayani area yang lebih luas penting untuk dilakukan guna penyediaan fasilitas perkotaan yang efektif.

\section{UCAPAN TERIMA KASIH}

Data pada studi ini merupakan bagian dari skema Riset Pengembangan dan Penerapan yang dibiayai selain APBN Tahun Anggaran 2019, Universitas Diponegoro. Peneliti mengucapkan terima kasih kepada Universitas Diponegoro yang telah memberikan dukungan sehingga penelitian ini dapat dilaksanakan dengan Surat Perintah Kerja (SPK) No. 474 - 36/UN7.P4.3/PP/2019. Terima kasih juga kepada seluruh pihak yang terlibat dalam kegiatan observasi lapangan.

\section{DAFTAR PUSTAKA}

Asfour, O. S., \& Zourob, N. (2017). The neighbourhood unit adequacy: An analysis of the case of Gaza , Palestine. Cities, 69(December 2016), 1-11. https://doi.org/10.1016/j.cities.2017.05.014

Average, C. (2019). Low income housing problems and low - income housing solutions : opportunities and challenges in Bulawayo. Journal of Housing and the Built Environment, 34, 927-938. https://doi.org/10.1007/s10901-019-09676-w

Baqutaya, S., Ariffin, A. S., \& Raji, F. (2016). Affordable Housing Policy: Issues and Challenges among Middle-Income Groups. International Journal of Social Science and Humanity, 6(6), 433-436. https://doi.org/10.7763/IJSSH.2016.V6.686

Eisner, S., Gallion, A., \& Eisner, S. (1993). Urban Pattern. New York: Van Nostrand Reinhold.

Habib, F., Moztarzadeh, H., \& Hodjati, V. (2013). The Concept of Neighborhood and its Constituent Elements in the Context of The Concept of Neighborhood and its Constituent Elements in the Context of. Advances in Environmental Biology, 7(9). 
Hasanuddin, N. L. (2014). Konsep Penerapan Prinsip-Prinsip Neighborhood Unit dalam Menunjang Interaksi Sosial pada Lingkungan Perumahan Nasional (Studi kasus: Perumnas Bumi Tamalanrea Permai, Makassar). Institut Teknologi Sepuluh Nopember.

Hasanuddin, N. L. (2019). Perkembangan Lingkungan Neighborhood Unit sebagai Penataan Fisik. Prosiding Seminar Nasional Desain Dan Arsitektur (SENADA), 2(Februari), 490-496.

Ibem, E. O. (2012). Accessibility of Services and Facilities for Residents in Public Housing in Urban Areas of Ogun State , Nigeria. Urban Forum, 24(3), 407-423. https://doi.org/10.1007/s12132-012-9185-6

Igwe, P. U., Okeke, C. A., Onwurah, K. O., Nwafor, D. C., \& Umeh, C. N. (2017). A Review of Housing Problems. International Journal of Environment, Agriculture and Biotechnology (IJEAB), 2(6), 30923099.

Jensen, O. (2020). Neighborhoods and Community. International Encyclopedia of Human Geography (Second Edition), 341-345. https://doi.org/https://doi.org/10.1016/B978-0-08-102295-5.10298-7

Karji, A., Woldesenbet, A., Khanzadi, M., \& Tafazzoli, M. (2019). Assessment of Social Sustainability Indicators in Mass Housing Construction: A Case Study of Mehr Housing Project. Sustainable Cities and Society, 50(July), 1-9. https://doi.org/10.1016/j.scs.2019.101697

Kellett, J., \& Nunnington, N. (2019). Infrastructure for new Australian housing: Who pays and how? is. Cities, 92(May 2018), 10-17. https://doi.org/10.1016/j.cities.2019.03.007

Lee, J., \& Park, S. (2018). Exploring Neighborhood Unit's Planning Elements and Configuration Methods in Seoul and Singapore from a Walkability Perspective. Sustainability, 10, 1-24. https://doi.org/10.3390/su10040988

Lestari, N., Faqih, M., \& Santosa, H. (2014). Konteks Lokal Neighborhood Unit dalam Perencanaan Lingkungan Perumahan. In Prosiding Seminar Nasional Aplikasi Teknologi Prasarana Wilayah (ATPW) (pp. 1-9).

Rachmawati, F., Asih, R., Soemitro, A., Joko, T., \& Adi, W. (2018). Critical success factor for partnership in low-cost apartments project: Indonesia perspective Critical success factor for partnership in low-cost apartments project: Indonesia perspective. Pacific Rim Property Research Journal, 5921, 1-12. https://doi.org/10.1080/14445921.2018.1461769

Sukmawati, A. M., \& Yuliastuti, N. (2014). Efektivitas Pemanfaatan Fasilitas Sosial di Perumahan Bukit Kencana Jaya Semarang. Jurnal Teknik PWK, 3(3), 371-381.

Sunarti, S., Yuliastuti, N., \& Indriastjario, I. (2018a). Kolaborasi Stakeholder dalam Penyediaan Perumahan untuk Masyarakat Berpenghasilan Rendah di Kota Salatiga. Tata Loka, 20(4), 455-471.

Sunarti, S., Yuliastuti, N., \& Indriastjario, I. (2018b). Stakeholder Collaboration in Provision of Housing for Low Income Community in Salatiga. Tata Loka, 20(4), 455-471.

Turner, J. F. C. (1976). Housing by People: Towards Autonomy in Building Environments. London: Marion Boyars.

Yuliastuti, N., Sukmawati, A. M., \& Purwoningsih, P. (2018). Utilization of Social Facilities to Reinforce Social Interaction in Formal Housing. International Journal of Architectural Research, 12(1), 134-151.

Zou, J., Chen, Y., \& Chen, J. (2019). The complex relationship between neighbourhood types and migrants' socio - economic integration: the case of urban. Journal of Housing and the Built Environment, (0123456789). https://doi.org/10.1007/s10901-019-09670-2 